\title{
HumAn Rights IN HONG KONG
}

\author{
Lord Cooke of Thorndon*
}

In this address to the UNDR commemorative seminar in April 1998 Lord Cooke speaks of human rights, his current judicial roles and the prospects for a common law of the world.

As it has not been said expressly by any previous speaker, let me begin with the proposition that 10 December 1948 may well be the most important date in legal history although, as Sir Kenneth has said, it should by no means be seen alone. The Universal Declaration of Human Rights was proclaimed by the General Assembly of the United Nations as a common standard of achievement for all peoples and all nations. A long, winding and at times dangerous road remains to be travelled before the common standard is substantially achieved; yet we have seen half a century without a world war and with many constitutional changes giving legal recognition to the declared rights; that is surely progress. Nor is the legal evolution by any means on paper only. Courts and other agencies of justice (such as Ombudsmen) in many countries are increasingly grappling avowedly with human rights issues. The Diceyan concept of the rule of law was that citizens may do what they like unless the State has sufficiently express powers of intervention. It is steadily being replaced by more positive thinking in terms of the identifiable rights of human beings which States are bound to respect and further. This is now as orthodox as Halsbury's Laws of England ${ }^{1}$ where virtually the same language is used in the title "Constitutional Law and Human Rights" of which Lord Lester of Herne Hill is a principal author.

This evening, although coming to Hong Kong, I propose to report briefly on how this process has been operating in each of the various jurisdictions where from time to time I

* Lord Cooke of Thorndon practised at the New Zealand Bar from 1955 to 1972. He was appointed a Judge of the Supreme Court of New Zealand in 1972 and was President of the New Zealand Court of Appeal between 1986 and 1996. He was created Baron Cooke of Thorndon in 1996 and for part of each year he sits in the Appellate Committee of the House of Lords and the Judicial Committee of the Privy Council.

1 4th ed Reissue 8(2) Constitutional Law and Human Rights (1996) - Para 101: "In England liberties have been treated as residual rather than fundamental and positive"; Para 105: "Traditionally the English Courts have been averse to expressing their reasoning in terms of rights, but recently rights-based reasoning has been adopted". 
now go on circuit - perhaps revolve on circuit is the appropriate word, although revolution would certainly not be, for one who has to swear an appropriate judicial oath to administer the established law in each country. The circuit does not include New Zealand, so it is easy to avoid that which I am resolved to avoid: to be drawn into comment, whether favourable or otherwise, on the performance of my successors here. That sort of thing does not come well from a retired judge, as fairly recent evidence in Australia confirms. Still less am I willing to join in the preparation of material intended to influence the present Court of Appeal, as was proposed to me recently. First, it would be incongruous. Secondly, as a source of any kind of public pressure, one could have no hope of competing with the Business Roundtable and other groups dedicated to and practised in promoting through the media particular policies.

There is, though, one point legitimately to be made to you by me about human rights in New Zealand. As you know, in the United Kingdom the Human Rights Bill, introduced into the House of Lords by the Lord Chancellor, Lord Irvine of Lairg, has passed through that House with only minor change and is now before the House of Commons. The Labour Government was committed to legislation incorporating into United Kingdom domestic law the European Convention for the Protection of Human Rights and Fundamental Freedoms. The Bill goes quite a long way in that direction, although not the whole distance. If primary legislation is intractably explicit, it will override Convention rights. Even so, the Courts may make declarations of incompatibility, and a fast-track procedure is made available whereby Ministers may amend statutes by remedial orders laid before the Houses of Parliament. The overriding power to overrule Acts of the United Kingdom Parliament will remain, however, with the European Court of Human Rights in Strasbourg.

Full and long discussion in and out of Parliament has accompanied the Bill. Various methods of enacting human rights have been canvassed. Again and again I have had to wince as informed commentators have spoken of the New Zealand legislation, the New Zealand Bill of Rights Act 1990, as weak, the weakest solution. Usually this is said dismissively. Regrettably for our international legal reputation, it is true. That is not the fault of our chairman, the Rt Hon Sir Geoffrey Palmer. But even the United Kingdom Government, who might be supposed to have preferred the least inhibiting legislation that could pass muster as incorporation, have given their Bill more teeth. Of course one has tried to defend the New Zealand Bill against the critics by pointing out that the courts have 
been able to give it some teeth - Baigent, ${ }^{2}$ Noort, ${ }^{3}$ and other cases - but the answer has not been accepted by knowledgeable overseas critics as satisfactory. It is a paradox that, whereas Baigent for instance is seen abroad as the best evidence that the New Zealand statute works up to a point, that case is the one most selected for attack by some academic lawyers and others in New Zealand itself. The essence of Baigent is that the enactment of a legal right is meaningless and window-dressing without a legal remedy; the appropriate remedy is the one most effective in the circumstances; it is the duty of the courts to provide legal remedies for the breach of legal rights. The more influential the anti-Baigent school of thought in this country, the more out of touch we will be with the trend towards internationally-recognised human rights which is so noticeable throughout the world. Noticeable in theory almost everywhere; noticeable in practice to an ever-growing extent, despite big problem areas, as Don MacKay has underlined.

The trend is healthy for two reasons. First, and obviously, because of its humanity. Secondly, because it is a counterweight to another form of globalisation about which an accomplished address entitled Globalisation and its Discontents was heard in this Law School on 9 February 1998 from a distinguished Canadian academic lawyer, Professor $\mathrm{H}$ W Arthurs - the tendency of the world's business, and hence the lives of its peoples, to be run from international business headquarters: the New York syndrome.

By way of reporting, I can do no more than skim over three of the circuit jurisdictions. Western Samoa, which has recently become simply Samoa, has a Constitution, United Nations-driven, with entrenched western-style human rights: balanced, however, by reference to indigenous custom and usage. Thus the custom of banishment from the village has been held to prevail over the right to freedom of movement, provided that it is preserved as an extreme judicial remedy to be used only when essential to maintain the stability of the local community.

The Republic of Fiji - about to become The Republic of the Fiji Islands - has moved from one post-coup Constitution to another; and from one set of human rights provisions to another. The new ones, potentially of great importance in that mixed-race society, remain to be tested. Rather unexpectedly, perhaps, an Australian draftsman was engaged. The human rights provisions in the 1990 Constitution, themselves largely untested, have been completely rewritten. Yet the day may be rather distant when any similar provisions will be found in the Australian Constitution.

2 Simpson v Attorney-General (Baigent's case) [1994] 3 NZLR 667; (1994) 1 HRNZ 42.

3 Ministry of Transport $v$ Noort [1992] 3 NZLR 260; [1990-92] 1 NZBORR 97. 
The pending United Kingdom Bill I have already touched on. Two points are worth making about it. First, a key provision is the interpretation canon, clause 3(1) -

So far as it is possible to do so, primary legislation and subordinate legislation must be read and given effect in a way which is compatible with the Convention rights.

The words that I have stressed are strong language, if anything even stronger than section 6 of the New Zealand Bill. And the Lord Chancellor has affirmed that it is meant to mean what it says. In a public lecture, ${ }^{4}$ during which he mentioned New Zealand jurisprudence, he stated:

The Act will require the courts to read and give effect to the legislation in a way compatible with the convention rights 'so far as it is possible to do so'. This ... goes far beyond the present rule. It will not be necessary to find an ambiguity. On the contrary the courts will be required to interpret legislation so as to uphold the convention rights unless the legislation itself is so clearly incompatible with the convention that it is impossible to do so.

$\cdots$

Moreover, it should be clear from the parliamentary history, and in particular the ministerial statement of compatibility which will be required by the Act, that Parliament did not intend to cut across a convention right. Ministerial statements of compatibility will inevitably be a strong spur to the courts to find means of construing statutes compatibly with the convention.

Whilst this particular approach is innovative, there are some precedents which will assist the courts. In cases involving European Community law, decisions of our courts already show that interpretative techniques may be used to make the domestic legislation comply with the community law, even where this requires straining the meaning of words or reading in words which are not there.

$\cdots$

The court will interpret as consistent with the convention not only those provisions which are ambiguous in the sense that the language used is capable of two different meanings but also those provisions where there is no ambiguity in that sense, unless a clear limitation is expressed. In the latter category of cases it will be 'possible' (to use the statutory language) to read the legislation in a conforming sense because there will be no clear indication that a limitation on the protected rights was intended so as to make it 'impossible' to read it as conforming.

4 Quoted by Lord Lester in (1998) 584 PD (Hansard) 1291-2. 
There can be no doubt that, if the courts prove willing to follow that approach, a dramatic change of statutory interpretation techniques will occur. Thus, while the United Kingdom Bill is at pains to maintain at least the facade of Parliamentary sovereignty, that venerable old friend will never be quite the same again. Such is the power of, ultimately, the Universal Declaration of Human Rights.

Secondly, the United Kingdom Bill seems largely to have been drawn with the powers of public authorities in mind. But, like our New Zealand Bill, it includes the Courts as public authorities bound by it. Thus, where the rights are capable of applying between citizens - in matters of privacy and defamation, for instance - they will extend beyond the public law sphere. The drafting has recently been criticised by as eminent an academic authority as Sir William Wade. He sees the structure of the Bill as confusing and illogical. But a significant indirect effect on the common law in the private sphere is probably already well established in New Zealand; nor am I conscious that any ill effects have followed. In my respectful opinion, the United Kingdom Bill has been drafted with skill and some subtlety. Those instructing the draftsman may have borne in mind that politics is the art of the possible. The draftsman introduced himself to me at a party in London, saying that he had profited from the New Zealand legislation. I asked for his card, which he gave somewhat reluctantly, as these people like to remain behind the scenes. But Edward Caldwell, Parliamentary Counsel, deserves an honourable mention, in the same breath as the late Denzil Ward.

So the United Kingdom is in the process of making a notable advance in the implementation of the Universal Declaration; while Fiji, Samoa and to some extent New Zealand have already gone down that road. But the circuit country (if I may be allowed to persist with that terminology) which has made the greatest advance on paper is Hong Kong, now a Special Administrative Region of the People's Republic of China. Much misconception is current in the west about the new constitutional arrangements in Hong Kong. In truth the hard bargaining between the United Kingdom and China which preceded the handover on 1 July 1997 culminated in guarantees of human rights reflecting great credit on both sides. In advance of the return of the territory to China, the colonial administration had introduced the Hong Kong Bill of Rights Ordinance 1991, expressly to provide for the incorporation into the law of Hong Kong of the International Covenant on Civil and Political Rights: something not done for the people of the United Kingdom itself. The rights were specified in 23 articles with some limited exceptions and reservations. Any pre-existing legislation not admitting of a consistent construction was declared to be repealed - a sweeping repeal indeed. Subsequent legislation was to be construed so as to be consistent 'to the extent that it admits of such a construction'. As I read the Basic Law of Hong Kong adopted by the National People's Congress of China in 1990 and now in operation, that qualification may have gone. The Basic Law follows and implements the Sino-British Joint Declaration of 1984. The broad scheme is based on the 
principle 'one country, two systems'. 'The socialist system and policies' will not be practised in Hong Kong, which will enjoy a high degree of autonomy and executive, legislative and independent judicial power, including that of final adjudication. The right of private ownership of property is to be protected: 'the previous capitalist system and way of life' shall remain unchanged for 50 years. The existing law shall be maintained, and while the Hong Kong Legislative Council and the National People's Congress both have legislative powers, no amendment of the Law shall contravene the established basic policies of the People's Republic of China regarding Hong Kong, which are those already indicated and go back to the Joint Declaration. For good measure the Basic Law itself directly affirms a variety of rights: these at least are apparently immune from repeal for 50 years.

The provisions safeguarding individual human rights are impressive. ${ }^{5}$ They are of three chief categories. First, by virtue of articles 8, 18 and 84, the Bill of Rights Ordinance, including the Bill of Rights itself, remains in force. Second, article 39 requires implementation of the International Covenants on Civil and Political Rights and on Economic, Social and Cultural Rights, and international labour conventions as applied to Hong Kong. Together the articles just mentioned import a sweeping range of rights: a range which could astonish new readers. Third, the Basic Law affirms directly a variety of rights, such as the equality of all Hong Kong residents before the law (article 25); the right to vote and stand for election in accordance with law (article 26); freedom of speech, of the press, and of publication; freedom of association, assembly, procession, demonstration; freedom to form and join trade unions and to strike (article 27); inviolable freedom of the person, security against arbitrary or unlawful arrest, detention or search, the prohibition of torture (article 28); the inviolability of the home and prohibition of unlawful or arbitrary search (article 29); privacy of communications, with a limited reservation in aid of the detection of crime (article 30); freedom of movement and travel (article 31); freedom of conscience and religious belief and choice of occupation (articles 32 and 33); the right to confidential legal advice, access to courts and choice of lawyers, and to judicial remedies, including the right to institute court proceedings against executive authorities (article 35); the right to social welfare in accordance with law (article 36); freedom of marriage (article 37). Even that list is not exhaustive. Subject to limited exceptions (see particularly articles 19 and 23) the Basic Law appears to give protected constitutional status to all these rights, free from curtailment (see articles 11 and 159). Subject again to a limited exception, all these rights will fall to be safeguarded by the Hong Kong judiciary in exercise of the Special Administrative Region's high degree of autonomy (see inter alia articles 2, 39, 82, 85, 158).

5 Some of what follows incorporates part of an address to Hong Kong Judges and Judicial Officers on 17 December 1997 entitled The Judge in an Evolving Society • 
Certainly there are some qualifications on the protected rights, but bearing in mind that the Basic Law has to be read as a whole it may be that in this context these do not have as much scope as critics sometimes suggest. Examples may bring this out. It is true that the power of amendment of the Law is vested in the National People's Congress; yet no amendment shall contravene the established basic principles of the People's Republic of China regarding Hong Kong (article 159), and these principles have been elaborated by the Chinese Government in the Sino-British Joint Declaration (as stated in the Preamble to the Basic Law). Similarly, article 11 restricts the power of the legislature of the Special Administrative Region in a corresponding way. In times of war or turmoil beyond regional control, relevant national laws may be applied in the Region pursuant to article 18; but the same article makes it clear that additions to the list of national laws applying in the Region, which list appears in Annex III, are confined to laws relating to defence and foreign affairs and other matters outside the specified Regional autonomy. In harmony with this are the special provisions of article 158 concerning affairs which are the responsibility of the Central People's Government, or concerning the relationship between the Central Authorities and the Region. The regional courts have no jurisdiction over acts of state such as defence and foreign affairs (article 19); but that is no whit surprising; and the meaning and scope of the limitation would fall for judicial interpretation if necessary, although on questions of fact involved the Chief Executive's certificate will be conclusive. The Special Administrative Region is to enact laws on its own to prohibit acts of sedition and the like and political activities by or ties with foreign political organisations or bodies (article 23); but these laws presumably could not derogate from rights such as freedom from arbitrary arrest and to a fair trial (article 87).

In combination the various Hong Kong documents produce a panoply of human rights entrenched for half a century more effectively, in terms, than are the corresponding rights in New Zealand, Samoa and Fiji or the rights shortly to be enacted in the United Kingdom. Legislative powers of amendment, for instance, by two-thirds majorities or after referenda, do not exist. The Universal Declaration is virtually enacted, with the possible exception of the right to leisure, something with which one does not naturally associate the pace of life in Hong Kong.

Of course, however impressive on paper, all this would be a charade if there were no will to implement it and no independent judiciary. As far as the judiciary are concerned, it appears to me that the will is there. The new Court of Final Appeal consists, at any sitting, of five judges, - normally the Chief Justice and three local permanent judges, with one non-permanent judge. There are two lists of NPJ's - a Hong Kong list and a list of judges from other common law countries. In theory the fifth member could be drawn from the Hong Kong list, but certainly at present that does not appear to be the policy of the Court. And it is with the Court that the choice rests under article 82 of the Basic Law. The overseas list consists at present of two New Zealanders, two Australians, 
one and a half Englishmen and half a South African. It is not conceivable that any of these six persons would be a party to a departure from the spirit of the Basic Law. At least that is true of the other five, and I hope the sixth as well.

This development should be seen in the context of changes taking place in mainland Chinese law. The Court of Final Appeal could serve as a bridge between western and eastern legal systems and cultures. So there is a crucial addendum with which to conclude. Traffic over the bridge should not be one way. While western law is entrenched for fifty years, in the course of time eastern influences will make their contribution. Thus the traditional Confucian emphasis on the family as a unit, which is compatible with western culture, seems likely to endure. As to what may ultimately emerge as a synthesis of systems, prediction would be rash. Without indulging in it, I mention a few cardinal principles which could commend themselves as fitting in any evolved civilised legal system, taking as examples the fields of administrative law, contract and tort or delict.

In administrative law, and in particular judicial review of discretionary administrative decisions, it may be affirmed that a concrete administrative act will not be accepted as lawful if it deviates from the objective of the relevant legislation, or is not based on relevant considerations, or is obviously unfair. The governing principle of tort law should be that there is civil liability where the actor through fault interferes with the property or person of another. And contract law should have at its heart the idea that civil activities must be carried out in accordance with the principles of voluntariness, fairness, exchange of equivalent values, honesty and good faith. I have taken the language of those propositions in those three fields from related sources. First, the Administrative Litigation Law of the People's Republic of China; second, the General Principles of Civil Law of the People's Republic of China; third, another article of the same General Principles. They are part of the massive reformulation of Chinese law dating from the later nineteen-seventies.

In the practical implementation of such principles, it is doubtless the case that China has quite a long way to go. But their proclaiming alone is of enormous significance. In some respects their terminology represents even an advance on the current state of the common law of English-speaking countries. It is cogent evidence that, very gradually but inevitably, mankind is moving towards a common law of the world. It will be a privilege to be a part-time member of a Hong Kong judiciary which, while cementing the rule of law there, may contribute significantly to that process.

And as a two-way bridge, let Bertrand Russell ${ }^{6}$ have the last word:

6 History of Western Philosophy (George Allen \& Unwin Ltd, London, 3rd impression, 1948) 419-20. 
Our superiority since the Renaissance is due partly to science and scientific technique, partly to political institutions slowly built up during the Middle Ages. There is no reason, in the nature of things, why this superiority should continue. In the present war, great military strength has been shown by Russia, China, and Japan. All these combine Western technique with Eastern ideology - Byzantine, Confucian, or Shinto. India, if liberated, will contribute another Oriental element. It seems not unlikely that, during the next few centuries, civilization, if it survives, will have greater diversity than it has had since the Renaissance. There is an imperialism of culture which is harder to overcome than the imperialism of power. Long after the Western Empire fell - indeed until the Reformation - all European culture retained a tincture of Roman imperialism. It now has, for us a West-European imperialistic flavour. I think that, if we are to feel at home in the world after the present war, we shall have to admit Asia to equality in our thoughts, not only politically, but culturally. What changes this will bring about I do not know, but I am convinced that they will be profound and of the greatest importance. 